\title{
A survey and review of the status of wild bees in the West-Palaearctic region*
}

\author{
Sébastien PATINY ${ }^{1}$, Pierre RASMONT ${ }^{2}$, Denis MicheZ ${ }^{2}$ \\ ${ }^{1}$ Entomologie fonctionnelle et évolutive, Faculté universitaire des Sciences Agronomiques de Gembloux, \\ Passage des déportés 2, 5030 Gembloux, Belgium \\ ${ }^{2}$ Laboratoire de Zoologie, Pentagone, Université de Mons-Hainaut, place du Parc, 20, 7000 Mons, Belgium
}

Received 10 October 2008 - Revised 19 January 2009 - Accepted 12 February 2009

\begin{abstract}
Bees (a.k.a. Apoidea Anthophila) are among the main pollinators in most ecosystems. The yearly value of the ecological services provided worldwide by pollinators reaches more than $€ 150$ billion. As in many other groups, the erosion of bee diversity is now a well-assessed reality. However, quantification of the phenomenon, including the assessment of its extent and severity has been lacking for a long time. In the West-Palaearctic, the decrease in wild bees has been highlighted in several studies over the last few decades. Specifically, the plight of a few populations of bees in Europe has been measured and assessed. In this paper, we review the state of the knowledge of bee diversity in the West-Palaearctic. We present the available resources usable for estimation of the extinction risk in West-Palaearctic bees. We also point out the work that is needed to outline a holistic picture of West-Palaearctic bee diversity. We conclude by suggesting that former initiatives should be integral in developing the framework of a subregion-wide monitoring program for bees.
\end{abstract}

\section{diversity / taxonomy / West-Palaearctic / Europe / Apoidea}

\section{INTRODUCTION}

Bees (Apoidea, Anthophila) constitute a $\sim 100$ Myrs old monophyletic group that today includes $\sim 17500-20900$ described species (Engel, 2000, 2001; Poinar and Danforth, 2006; Michener, 2007; Ascher et al., 2008: www.discoverlife.org). In contrast to most other pollinating herbivores, bees rely almost exclusively on flowers for protein, fat, and sugar throughout their life cycle (Linsley, 1958; Thorp, 1979, 2000; Eickwort and Ginsberg, 1980; Michener, 2007). Based on floral pollination syndromes (i.e. the presence of floral traits selected for their role in attracting pollinators), it can be estimated that ninety percent of all angiosperms (i.e., about 90\% of $240000 \mathrm{spp}$.) are adapted to insect polli-

Corresponding author: S. Patiny, patiny.s@gmail.com

* Manuscript editor: Mark Brown nation, with bees being the main pollinators in most ecosystems (Proctor and Yeo, 1973; Buchmann and Nabhan, 1996; Costanza et al., 1997; Pimentel et al., 1997; Renner, 1998).

The tight association with flowering plants and the global geographical distribution of bees make them the keystone in the delivery of pollination services within most ecosystems. Annually, bees provide a free ecological service estimated to several billion $\mathrm{US} \$ / €$ in regions such as the USA or Europe (Buchmann and Nabhan, 1996; Costanza et al., 1997; Pimentel et al., 1997; CBD, 2001; Buchmann and Ascher, 2005; Losey and Vaughan, 2006; Klein et al., 2007). In 2005, the worldwide value of crop pollination amounted to $€ 153$ billion (Gallai et al., 2009). A significant part of that production relies upon the activity of pollinators, notably bees. The increasingly observed decline of bees consequently constitutes a 


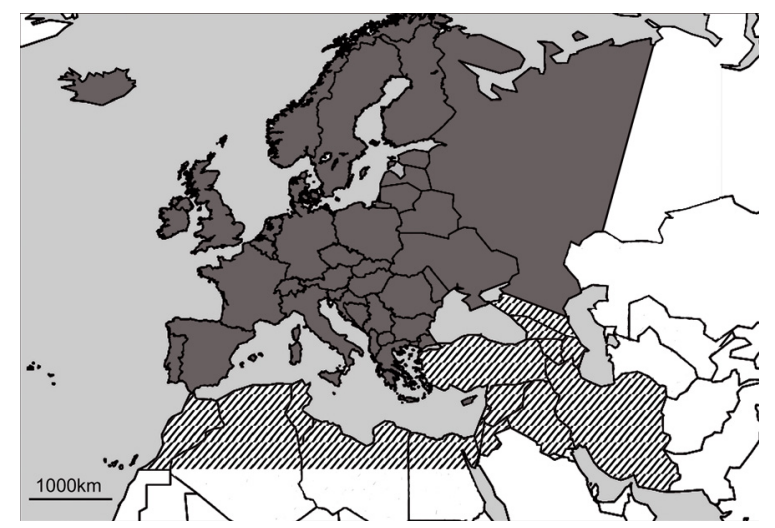

Figure 1. Geographical framework of the European study "Fauna Europaea" (dark grey, including Canarian and Macronesian islands) and West-palaearctic region (dark grey and hatched black).

major concern and a global threat to wild plants and crop production (e.g. Williams P.H., 1985; Rasmont and Mersch, 1988; Cane and Tepedino, 2001; Kevan and Phillips, 2001; Ashmann et al., 2004; Buchmann and Ascher, 2005; Biesmeijer et al., 2006; Oldroyd, 2007). Given the economic and ecological importance of bees (including wild bees) there is a true urgency for developing specific conservation strategies.

One central obstacle in estimating the global extinction risk for bees follows from the lack of documented archives (databases, former works, etc.) concerning their diversity at this global scale. Studies of $\alpha$ - and $\beta$-diversity (see below for definitions) are abundant and notably informative at the local scale: populations, communities or countries. By contrast, very few works have aimed so far at studying the $\gamma$-diversity of bees, addressing directly questions about the richness distribution at a higher scale (regional-subregional).

The present paper aims mainly at inventorying the resources available for risk assessment in West-Palaearctic bees and to point out the main weaknesses of the current knowledge. We begin by defining the terms and concepts we will be using. Next, we present the available (published and online) sources of information documenting the bee diversity in the West-Palaearctic subregion. Finally, we consider the relevant monitoring strategies for bee diversity at the West-Palaearctic scale.

\section{DEFINITIONS}

West-Palaearctic: In the following discussion, we do not follow the strict textbook definition of the West-Palaearctic as given, for instance, in De Lattin (1967). Rather, we consider the West-Palaearctic to be that part of Eurosiberia and northern Africa, which is limited southward by the Sahara and eastward by the Urals (Fig. 1).

Novaya Zemlya is the most northern part of the West-Palaearctic from which bees (bumblebees) have been recorded. There is so far no record of bees in Spitsbergen or Franz Joseph Land (the most northern parts of the subregion).

To the north-east, we consider the Ural Mountains as the West-Palaearctic limit. Western Siberia, between the Ural, Altay and Sayan Mountains, constitutes a large area of overlap for the Western- and Eastern-Palaearctic faunas. Given the current severe shortage of knowledge for that part of the Palaearctic, we will not discuss further the conservation issues in that part of the Palaearctic and thus we consider the West-Palaearctic limit as following the Urals.

To the south-east, we extend the limits of the considered area across some parts of the Near- and Middle East: Anatolia, Caucasus Iran, Iraq, Syria, Lebanon, Israel and Jordan. The Kopet Dag ridge, between Turkmenistan and Iran defines the south-eastern limit of the considered area. The Karakum desert is 
considered as a natural south-eastern border of the subregion.

Morocco, Algeria, Tunisia and Libya fall naturally into the definition of the WestPalaearctic subregion. Contrary to the southern part of Libya, the very coastal region of Benghazi is also naturally included in the West-Palaearctic. Inclusion of Egypt must be questioned; the Nile valley seems to play a corridor role between Ethiopian and Mediterranean faunas (Patiny, 2004).

Europe: The definition of Europe, follows that of Fauna Europaea. This central part of the subregion is defined according to its current political eastern and southern borders. However, it also includes Norway, Switzerland and the countries of Central Europe (e.g., former Yugoslavia) (Fig. 1).

$\alpha$-, $\beta$-, $\gamma$-diversities: Diversity levels are defined according to Cody (1975) in Whittaker et al. (2001). $\alpha$-diversity is the species richness within local communities/patches; $\beta$-diversity incorporates the phenomenon of turnover of species between communities, or inventories the whole landscape; $\gamma$-diversity measures the regional diversity and measures phenomena such as the differential overlap of species and ranges. Alternatives to the Whittaker et al. (2001) partitioning of diversity have been proposed (Crist et al., 2003) and used successfully in several recent studies (Tylianakis et al., 2005; Hendrickx et al., 2007). However, their application in the current paper to bees would require reconsidering datasets individually, which is not among the goals of the present paper.

Species richness $(S R)$ : Number of species, implying of itself no standardization of sampling (defined according to Whittaker et al., 2001).

\section{BEE DIVERSITY IN WEST-PALAEARCTIC REGION}

The knowledge of bees in the WestPalaearctic is quite uneven. A review of the main published checklists (country level) and red lists provides an insightful overview of the available local resources (Tab. I). The species records quoted below (Tab. I) highlight the significantly better coverage of the European part of the West-Palaearctic than of its eastern (western Central Asia, Near- and MiddleEast) and southern margins (North Africa). We therefore discuss the European and the other West-Palaearctic faunas separately.

The percentage of red listed species in each region/country would have been an interesting addition to Table I. However, the variety of the criteria applied to define the red listed species and the lack of red-lists for numerous regions make such a statistic irrelevant in a broad scale without a standardized analysis of each country fauna.

\subsection{Europe}

Despite notable gaps in the coverage (e.g. in southern Central Europe), the current knowledge of the European bee fauna is robust enough to support preliminary analyses of the species diversity and distributional trends (Fig. 1). Polaszek (2005) drew up the first modern list of the European bees including 69 genera and 2048 species of bees (i.e. 10\% of the global bee diversity) (Tab. II). By updating the specific diversity of some taxa (Melittidae, Panurginae, Apidae, Osmiini), we can confirm Polaszek's first approximation of European species richness.

In continental Europe, Finland has a very low species richness value for bees (230 species), while species richness peaks in the warm temperate xeric ecosystems of the Mediterranean area (Southern France, Spain and Turkey). In that context, the 134 species recorded in Portugal, while Spain scores 1056 (which is likely underestimated), seems obviously too low and underestimated. Likewise, only 17 species are recorded by the Fauna Europaea initiative in Andorra, which is a lower estimate than the diversity of just the bumblebees in the neighboring Valley of Eyne (France, Pyrénées-Orientales) (Iserbyt et al., 2008). It seems likely that, even if particularly depleted due to its specific soil occupation, the Andorran diversity is higher. More important with respect to total land surface within Europe, the very low diversity in Albania (46), Bosnia (11) and Croatia (165) is highly likely 
Table I. The most comprehensive bee checklists for West-Palaearctic countries or regions. $\mathrm{N}=$ number of listed species.

\begin{tabular}{|c|c|c|}
\hline Region/Country & $\mathrm{N}$ & Reference of check list - Reference of red list \\
\hline \multicolumn{3}{|l|}{ REGION } \\
\hline Central Asia & 307 & Popov (1967) \\
\hline Europe & 2065 & Polaszek (2005) \\
\hline French-speaking Europe & 913 & Rasmont et al. (1995) \\
\hline Iberian Peninsula & 1043 & Ceballos et al. (1956) \\
\hline \multicolumn{3}{|l|}{ Country } \\
\hline Andorra & 35 & Zanden (1958) \\
\hline Austria & 647 & Schwarz and Gusenleitner $(1997,1999)$ \\
\hline Azores & & Borges et al. (2005) \\
\hline Belgium & 376 & Pauly (1999), Leclercq et al. (1980), Rasmont et al. (1993) \\
\hline Canary Islands & 122 & Hohmann et al. (1993) \\
\hline Channel Islands & & Richards (1979) \\
\hline Czech Republic & 584 & Bogusch et al. (2007), Straka et al. (2008) \\
\hline Denmark & 239 & Warncke (1986) \\
\hline Finland & 230 & Elfving (1968), Rassi et al. (2001) \\
\hline France & 865 & Rasmont et al. (1995) \\
\hline Germany & 547 & Schwarz et al. (1996), Westrich et al. (1998) \\
\hline Iceland & 3 & Petersen (1956), Prys-Jones et al. (1981) \\
\hline Ireland & 102 & Stelfox (1927), Fitzpatrick et al. (2006) \\
\hline Italy & & Pagliano (1994) \\
\hline Latvia & 18 & Spuris (1998) \\
\hline Liechtentsein & 233 & Bieri $(2002)$ \\
\hline Lithuania & 322 & Monsevicius $(1995 \mathrm{a}, \mathrm{b})$ \\
\hline Luxembourg & 274 & Rasmont et al. (1995) \\
\hline Madeira & 20 & Fellendorf et al. (1999) \\
\hline Netherlands & 338 & Peeters et al. (1999) \\
\hline Poland & 454 & Banaszak (1991) \\
\hline Portugal & & Diniz (1960) \\
\hline Slovakia & 643 & Bogusch et al. (2007) \\
\hline Slovenia & 555 & Gogala (1999) \\
\hline Spain & 1046 & Ceballos et al. (1956) \\
\hline Sweden & 294 & Nilsson (2003), Gärdenfors (2005) \\
\hline Switzerland & 580 & Schwarz et al. (1996), Amiet (1994) \\
\hline United Kingdom & & Fitton et al. (1978) \\
\hline
\end{tabular}

to be a subregion-wide artifact due to a lack of knowledge, rather than an absence of bee species. Working in neighboring areas, Gogala (1999) listed 555 species of bees in Slovenia and Straka et al. (2008) counted 681 species in the Czech Republic and Slovakia. The Fauna Europaea records have the accuracy needed to draw a rough picture of the distribution of species richness in the European framework (Fig. 2). By contrast, a refined picture of the distributional trends of diversity across Europe requires the availability of more accurate and well assessed databases.
The general distribution of bee species richness in the West-Palaearctic matches well with that observed in many other taxa (see Hewitt, 1999; Berggren et al., 2005; Joger et al., 2007 for examples). As a rule of the thumb, the Mediterranean basin and the Mediterranean peninsulas in particular, harbour more diverse faunas and constitute the extremity of a positive diversity gradient extending from the north to the south-western and the south-eastern West-Palaearctic. Mapping bee diversity according to www.faunaeur. org, highlights a general North-South positive 
Table II. Specific and generic diversity in Europe (according to Polaszek, 2005 for Apoidea). Systematics according to Michener (2007). In brackets, species richness updated by authors.

\begin{tabular}{|c|c|c|c|c|c|}
\hline Family/ subfamily & Genus & No. sp. & Family/ subfamily & Genus & No. sp. \\
\hline ANDRENIDAE & 5 genera & 447 (433) & HALICTIDAE & 11 genera & $348(341)$ \\
\hline Andreninae & Andrena & 396 & Rophitinae & Dufourea & 17 \\
\hline \multirow[t]{4}{*}{ Panurginae } & Cатртороеит & $5(4)$ & & Rophites & $13(8)$ \\
\hline & Melitturga & 4 & & Systropha & $4(2)$ \\
\hline & Panurginus & 12 & Nomiinae & Nomia & 6 \\
\hline & Panurgus & $30(17)$ & & Pseudapis & 6 \\
\hline APIDAE & 23 genera & $602(594)$ & Nomioidinae & Ceylalictus & 1 \\
\hline \multirow[t]{2}{*}{ Xylocopinae } & Ceratina & 27 & & Nomioides & 3 \\
\hline & Xylocopa & 7 & Halictinae & Halictus & 85 \\
\hline \multirow[t]{7}{*}{ Nomadinae } & Ammobates & 16 & & Lasioglossum & 172 \\
\hline & Ammobatoides & 4 & & Sphecodes & 40 \\
\hline & Biastes & 3 & & Thrincohalictus & 1 \\
\hline & Epeolus & 17 & MEgachILIDAE & 25 genera & 476 (459) \\
\hline & Nomada & 202 & Megachilinae & Afranthidium & 4 \\
\hline & Parammobatodes & 2 & & Aglaoapis & 1 \\
\hline & Pasites & 1 & & Anthidiellum & 2 \\
\hline \multirow[t]{14}{*}{ Apinae } & Amegilla & $16(11)$ & & Anthidium & 30 \\
\hline & Ancyla & 3 & & Chalicodoma & 18 \\
\hline & Anthophora & $84(65)$ & & Chelostoma & $13(22)$ \\
\hline & Apis & 1 & & Coelioxys & 28 \\
\hline & Bombus & $61(72)$ & & Creightonella & 1 \\
\hline & Cubitalia & 1 & & Dioxys & 11 \\
\hline & Epeoloides & 1 & & Eoanthidium & 1 \\
\hline & Eucera & 78 & & Haetosmia & $1(2)$ \\
\hline & Habropoda & 3 & & Heriades & $15(8)$ \\
\hline & Melecta & $23(27)$ & & Hofferia & 2 \\
\hline & Tarsalia & 2 & & Hoplitis & $89(93)$ \\
\hline & Tetralonia & 30 & & Icteranthidium & 5 \\
\hline & Tetraloniella & 8 & & Lithurgus & 3 \\
\hline & Thyreus & $12(14)$ & & Megachile & 82 \\
\hline Colletidae & 2 genera & 137 & & Metadioxys & 1 \\
\hline Colletinae & Colletes & 58 & & Osmia & $114(87)$ \\
\hline Hylaeinae & Hyaleus & 79 & & Protosmia & $11(13)$ \\
\hline MELitTidae & 3 genera & 38 & & Pseudanthidium & 7 \\
\hline Dasypodainae & Dasypoda & 19 & & Rhodanthidium & 7 \\
\hline \multirow[t]{6}{*}{ Melittinae } & Macropis & 3 & & Stelis & 23 \\
\hline & Melitta & 16 & & Stenoheriades & 2 \\
\hline & & & & (Stenosmia) & (1) \\
\hline & & & & Trachusa & 5 \\
\hline & & & Sum & 69 genera & 2048 \\
\hline & & & & (70 genera) & (2002) \\
\hline
\end{tabular}

gradient, matching the general conclusions in Michener (1979) (i.e. an optimum of diversity centered on warm xeric areas, which in Europe is the Mediterranean basin).

Several features have been proposed to explain the polarity of the bee diversity gradient from mesic to xeric ecosystems: (i) the more favorable energy/water balance of the Mediterranean areas (Patiny et al., 2009); (ii) the likely role of refuges played during the Quaternary glaciations by the concerned areas (Reinig, 1937; De Lattin, 1967); (iii) the increase of diversity due to an increase in specialization (i.e. oligolectism) in the less predictable rainfall 


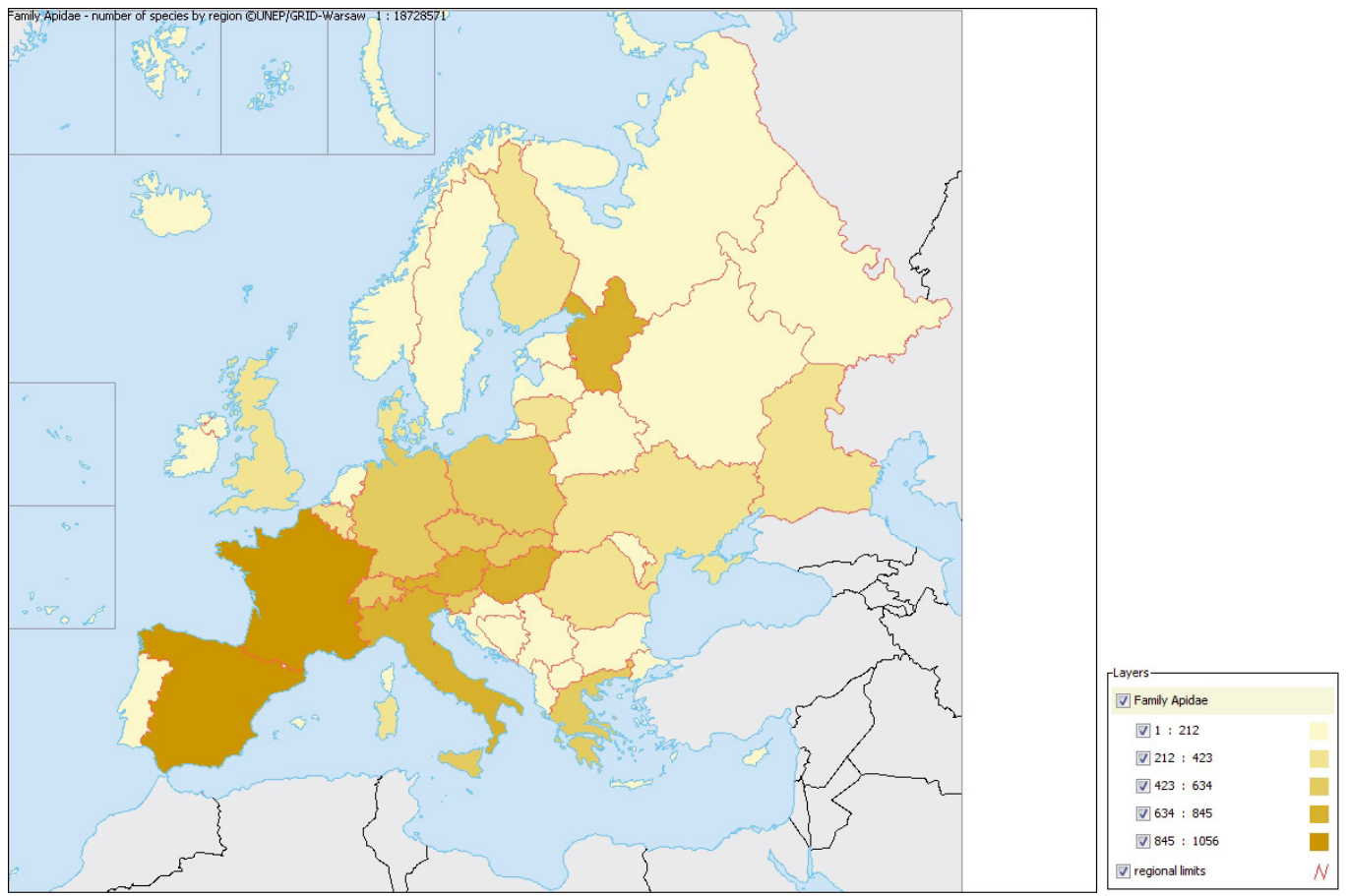

Figure 2. Map of the bee species diversity according to Fauna Europaea (http://www.faunaeur.org/: August, 2008).

areas (Minckley et al., 2000); (iv) archaic groups of bees probably originated and have survived in xeric areas (Michener, 1979).

The relative importance of these four features in determining bee diversity is very difficult to evaluate and probably varies across the world. The role of oligolectism in high bee diversity is not assessable in Europe due to a lack of basic accurate estimation of oligolectism ratios in different European ecosystems (but see Müller and Kuhlmann, 2008 for data on oligolectism in Colletes). Pekkarinen (1997) showed a positive gradient of oligolectism from Northern to Southern Scandinavia but he did not consider Mediterranean areas. However, rainfall has similar levels of predictability in Northern and Southern Europe, which contrasts with the situation in Western American deserts where this feature has been proposed as one of the most important environmental features driving bee specialization and bee diversity (Minckley et al., 2000). Unpredictable rainfall is perhaps therefore unlikely to explain Mediterranean richness in Europe.

Many archaic groups (e.g. Melittidae, Fideliinae, Rophitinae) as well as some derived groups (e.g. Eucerini, Anthophorini) show highest species richness in xeric areas (Michener, 1979). In the light of recent phylogenetic analyses (e.g. Roig-Alsina and Michener, 1993; Danforth et al., 2004; Patiny et al., 2008), they probably arose in these areas. As most bees are soil nesting (Michener, 2007), rapid rotting of pollen stores due to soil humidity could be part of the explanation of the low probability for bee groups to switch from a xeric habitat to a mesic (or tropical) habitat, explaining the global peak in diversity of bees in xeric areas. However, this hypothesis remains untested.

Consequently, the only drivers of bee diversity across Europe that have been rigorously established are the more favorable energy/water balance and refugia during recent glaciations. 


\subsection{Eastern and Southern West-Palaearctic}

As a consequence of multiple factors, notably the extent of the concerned areas, the background of knowledge for the eastern part of the West-Palaearctic is particularly sketchy and weak. For these areas, large systematic studies that have compiled large amounts of data for whole groups (e.g. Warncke, 1973; Kuhlmann, 2005; Terzo and Rasmont, 2004; Michez and Patiny, 2006) are among the main source of information. Some notably extensive works nevertheless suggest a high level of subregional species richness (Popov, 1967; Osytschnjuk, 1977). Likewise, Turkey, Iran and probably also former Mesopotamia are assumed to support particularly rich bee faunas (Warncke, 1979, 1987).

Based on original datasets for duly chosen model taxa, patterns in the distribution of species richness in the southern WestPalaearctic have been described in a couple of papers (Patiny and Michez, 2007; Patiny et al., 2009). These latter studies have shown that (i) Maghreb and the Nile delta have remarkably high species richness; (ii); Morocco constitutes remarkable hotspot for bee species richness; (iii) The area between western Egypt and southeastern Tunisia is, by contrast, characterized by a very low level of species richness. Based on a multivariate analysis of the macroecological parameters of the species richness distribution in the southern West-Palaearctic, Patiny et al. (2009) concluded that the patterns of species richness in Saharan Africa (northern and southern) are ruled by the water/energy balance within ecosystems, which impacts on bees through their feeding resources (i.e. flowering plants). Together with the view described above of the distribution of species richness in Europe, the pattern in the Saharan area confirms that the southern Mediterranean faunas constitute the end of an increasing north-south gradient of bee diversity.

These conclusions can be easily reconciled with Michener's (1979) former conclusions. In the northern West-Palaearctic, where water is not limiting, species richness seems to range across a latitudinal gradient, which corresponds to increasing levels of energy and xericity within ecosystems. In Saharan Africa, even in its moister Mediterranean margin, water plays a stronger role, determining the presence, abundance and nature of the flowering plant communities. Water is consequently acting as a limiting factor.

However, contrary to the situation observed in the North-American deserts studied by Minckley et al. (2000), the Sahara also includes a central zone where the level of aridity suggests that climate controls the spatial and temporal randomization of populations.

\section{DIVERSITY EROSION IN THE WEST-PALAEARCTIC}

In some European countries, up to $65 \%$ of the bee species have been red listed (see references in Tab. I), indicating the severity of species declines in the less diverse part of the West-Palaearctic. As discussed hereafter, the main causes of this seem to be anthropogenic (reviewed in Murray et al., 2009). It is likely that similar erosion is occurring in the southern and eastern West-Palaearctic. The likely causes of erosion in these latter areas, while still anthropogenic in origin, may be somewhat different. Due to the generally lower density of human population in the southern and eastern West-Palaearctic, one can assume that the anthropogenic impact is more scattered in the southern West-Palaearctic (except in areas like Israel, the Nile Valley or the shores of Maghreb). Nevertheless, due to the distribution of climates and the subsequent range of ecosystems (steppes and deserts), the impact of even minor ecological changes caused by human impact are likely to constitute more severe threats in the extreme northern and extreme southern West-Palaearctic.

\subsection{Global factors of decline}

Despite its inability to provide a single homogeneous and accurate picture of the bee diversity in the West-Palaearctic, the available knowledge (Tabs. I-III, Fig. 2) can serve in identifying the likely source of the bee decline in Europe. 
Table III. Importance of recent taxonomic revisions in the estimation of bee biodiversity in North-WestPalaeartic and Afrotropical regions.

\begin{tabular}{|c|c|c|c|c|}
\hline Taxon & $\begin{array}{l}\text { SR before } \\
\text { revision }\end{array}$ & $\begin{array}{c}\text { New species } \\
\text { described }\end{array}$ & $\begin{array}{c}\text { Proportion of recent } \\
\text { new species in SR }\end{array}$ & Major reference \\
\hline \multicolumn{5}{|c|}{ WEST-PALAEARCTIC } \\
\hline Camptopoeum & 26 & 3 & 10.3 & Patiny (1999b, 2001) \\
\hline Clavipanurgus & 8 & 2 & 20.0 & Patiny (1999b, 2001) \\
\hline Dasypoda & 23 & 6 & 20.7 & Michez et al. (2004) \\
\hline Eremaphanta & 7 & 1 & 12.5 & Michez and Patiny (2006) \\
\hline Flavomelitturgula & 4 & 2 & 33.3 & $\begin{array}{l}\text { Patiny (1999a, 2001); Patiny and Gaspar } \\
(2000)\end{array}$ \\
\hline Flavipanurgus & 5 & 1 & 16.6 & Patiny $(1999 b, 2001)$ \\
\hline Melitta & 16 & 1 & 5.8 & Michez and Eardley (2007) \\
\hline Melitturga & 10 & 1 & 9.1 & $\begin{array}{l}\text { Patiny (1999a, 2001), Patiny and Gaspar } \\
(2000)\end{array}$ \\
\hline Panurgus & 32 & 2 & 5.8 & Patiny $(1999 b, 2001)$ \\
\hline Systropha & 8 & 1 & 11.1 & Patiny and Michez (2006) \\
\hline \multicolumn{5}{|l|}{ AFrICA } \\
\hline Capicola & 7 & 6 & 46.0 & Michez et al. (2007) \\
\hline Melitta & 3 & 3 & 50.0 & Eardley and Kuhlmann (2006) \\
\hline Nomioinae & 26 & 7 & 21.0 & Pesenko and Pauly (2005) \\
\hline Samba & 5 & 4 & 44.4 & Michez et al. (unpubl. data) \\
\hline Scrapter & 36 & 11 & 23.0 & $\begin{array}{l}\text { Davies and Brothers (2006), Davies et al. } \\
\text { (2005) }\end{array}$ \\
\hline Rediviva & 10 & 14 & 58.0 & $\begin{array}{l}\text { Whitehead and Steiner (2001), } \\
\text { Whitehead et al. (2008) }\end{array}$ \\
\hline
\end{tabular}

The causes of the bee populations' plight in Europe and in the US converge in numerous points (Rasmont and Mersch, 1988; Shepherd et al., 2003; Buchmann and Ascher, 2005; Biesmeijer et al., 2006; Klein et al., 2007; Müller et al., 2006). The main causes highlighted are: (i) fragmentation of habitats and changes in land use; (ii) decreases in flower diversity and quantity (the shift to intensive monocultures led to a strong decrease of both wild and cropped plant diversity; see Fig. 3 and Rasmont and Mersch, 1988); (iii) insecticides and the direct or indirect toxicity of other agricultural inputs (for instance, see Rasmont (2008) and Tylianakis et al. (2008) for discussion of the impact of nitrogen deposition); (iv) physical barriers (e.g. roadways, highways). Several authors have also emphasized the danger represented by the fast expansion of alien taxa (Dafni and Shmida, 1996; LopezaraizaMikel et al., 2007; Haddad et al., 2008; Stout and Morales, 2009).

In their analysis of the problem, Biesmeijer et al. (2006) also highlighted habitat loss and agricultural change as the causes of the strong reduction observed in the bee species richness in Britain and the Netherlands.

Only a few studies have addressed so far the impact of global ecological change on populations (Memmott et al., 2007; Tylianakis et al., 2008). The direct impact of climate warming is easy to project based on the conclusions of studies such as that of Williams P.H. et al. (2007) or Patiny et al. (2009). However, one must also consider more insidious impacts as for instance a phenological disruption (Memmott et al., 2007) between pollinators and pollinated plants, an increased impact in regions with a high proportion of flower-specialists (Minckley et al., 2000) or a cascade effect on interdependent ecological mechanisms (Tylianakis et al., 2008).

Similar projections could not be made for the most southern and eastern parts of the subregion, because the background of available data describing the local species richness of bees is too fragmentary to predict the changes of populations and species richness through 


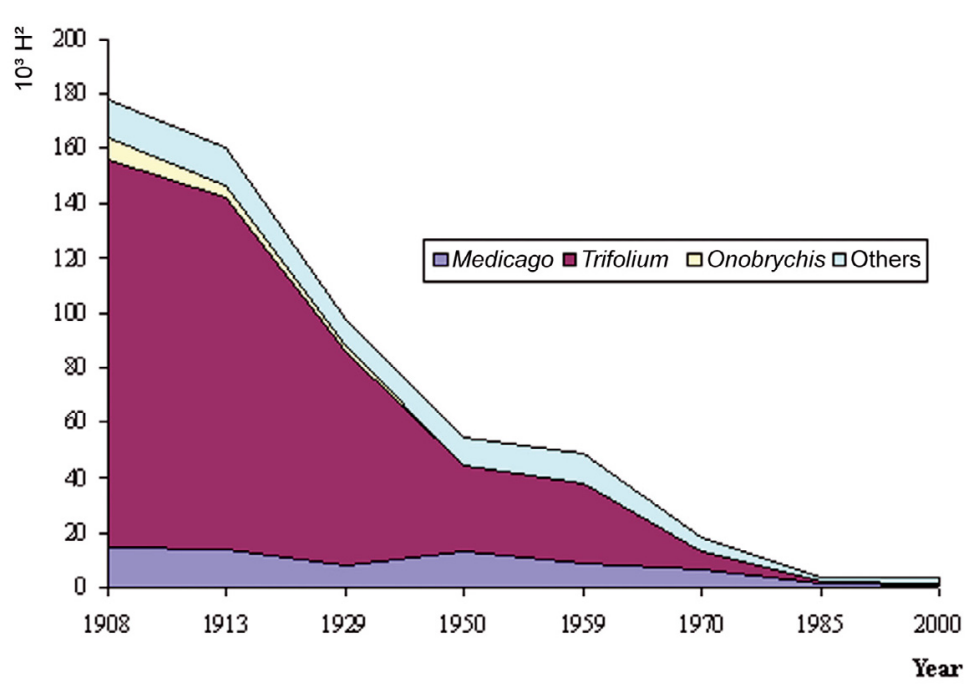

Figure 3. Cultivated area of leguminous plants as fodder crops in Belgium (modified from Rasmont and Mersch, 1988).

time and a fortiori to hypothesize about the causes of that evolution.

However, based on the characterization of the water/energy balance as a main driver of species richness in northern Africa (Patiny et al., 2009), one can speculate that the predicted (and observed) increase of drought is likely to impact on bee species richness, amplifying the natural trend ongoing since the end of the greening Sahara (Broström et al., 1998; Levis et al., 2004).

Changes in agricultural practices can be regarded a major source of threats for bees in the southern West-Palaearctic countries too. According to the FAO statistics, the production of cereals, meat and fruits-vegetables has more than doubled between 1979-1981 and 2004 (FAO yearbook online: http://www.fao. org/statistics/; August, 2008). During the same period, the same indicators have been stable in most European countries with, however, higher indices in Spain and Turkey. Behind the simple impact of the surface occupied and the related changes in landscapes, the related increased use of pesticides, the disruption of the nitrogen cycle (Rasmont, 2008; Tylianakis et al., 2008) and the expansion of alien species can be viewed as other potential threats (listed according to an estimated decreasing gradient of severity) for the subregional bee populations.

\subsection{Case studies}

As expected after Minckley et al. (2000), the decline in bee populations seems more significant in habitat and flowers specialist bees (Rasmont et al., 1993; Biesmiejer et al., 2006). Several studies have highlighted a correlation between the decrease of legume crops and the decline of specialist legume bees like species of bumblebees (genus Bombus), leaf cutter bees (genus Megachile) or mining bees (genus Andrena) (Rasmont and Mersch, 1988; Rasmont et al., 1993; Patiny, 1998; Müller et al., 2006). Rasmont and Mersch (1988) have noticed that the decrease of legume crops (Fabaceae) seems a sufficient explanation for the decline of most bumblebee species in Belgium (Fig. 3). Another likely victim of the decrease of legume cropping is Megachile parietina (Geoffroy) (=Chalicodoma muraria (Retzius)). Rasmont (2003) and Müller et al. (2006) observed a decline of this species in Europe where it was very widespread in most of France (Fig. 4). Decades ago, M. parietina was even regarded as a pest, as it built 

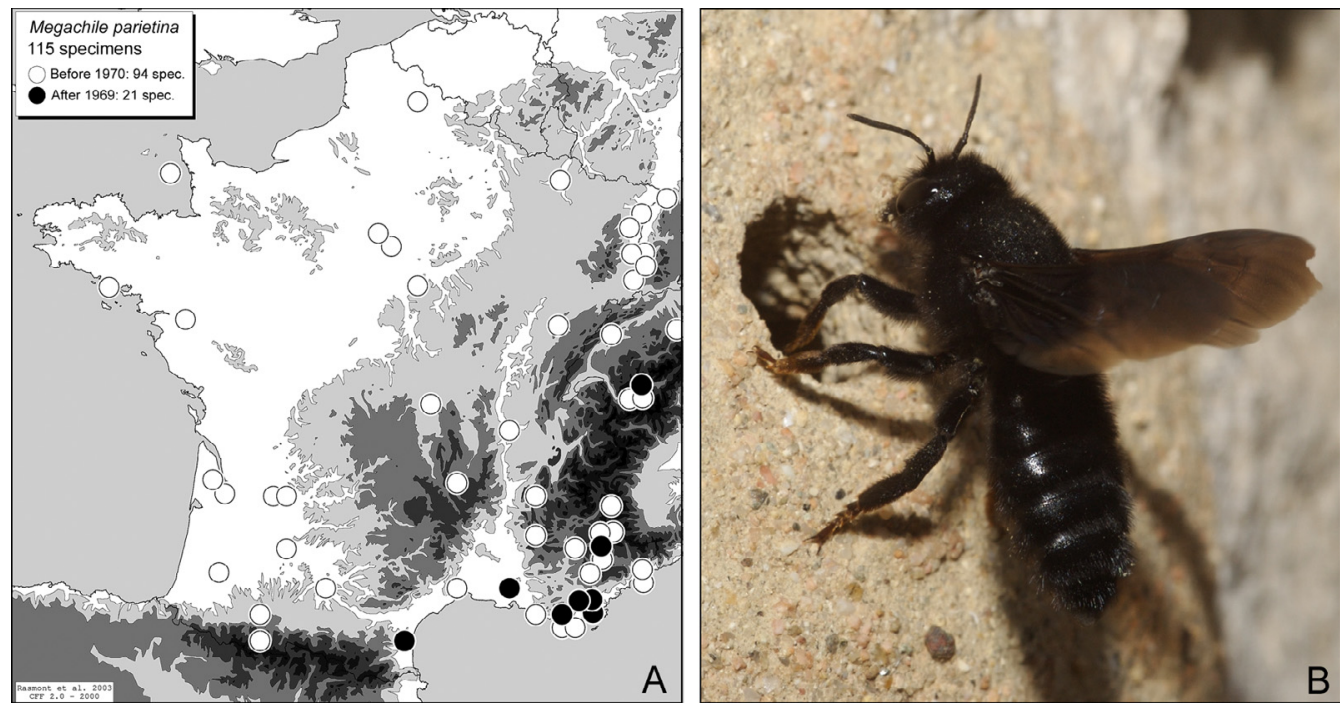

Figure 4. A. Collecting localities of Megachile parietina (Geoffroy, 1785) in France and Belgium after and before 1970 (according to Rasmont, 2003). B. Female of M. parietina (picture N. Vereecken).

large and heavy constructions on many human buildings. The famous French entomologist, Jean-Henri Fabre (1823-1915), took the large aggregations of this species as a favorite subject of observation. Nowadays, Megachile parietina has become an extremely rare species in most parts of its former distribution (Fig. 4).

\section{THE TAXONOMIC IMPERATIVE IN SURVEYING THE WEST-PALAEARCTIC BEES}

We noted above that a central unit in conservation is diversity. Independent of spatial scale, diversity is most often measured as a function of species richness and abundance (Weber et al., 2004). In the absence of measures of abundance in West-Palearctic bees, we are currently limited to trying to measure and understand species richness as a surrogate for diversity. Species richness surveys through time and space require the identification of species, in order to define their spatial distribution and to follow the evolution of their populations through time. Surveys of species richness consequently rely upon taxonomy and systematics.
Without names, data cannot be unambiguously shared (Ungricht et al., 2008). The role of taxonomy is therefore essential to reliably survey populations in general and bees specifically. The use of existing taxonomic expertise is the sole relevant way to estimate $\gamma$-diversity.

Taxonomic research on bees in Europe has a very rich history. European authors, as for instance Linné (1707-1778), Kirby (17591850), Latreille (1762-1833) and Lepeletier (1770-1845) were the first taxonomists to describe bees. Their abundant type material is still well conserved and available in a few famous European institutions. In an approach that has become unusual, these authors worked at very large geographical and taxonomic scales, often aiming at the production of general syntheses (e.g. Friese, 1901: die Bienen Europas). The community of European bee taxonomists became strongly impoverished during the second part of the 20th century. Many of the modern taxonomists turned to more applied, fundamental or local approaches. This change in systematic expertise is interestingly documented by the ETI database (http://www.gti-kontaktstelle.de/ taxonomy_E.html). There is consequently a unique wealth of publications about bees in Europe but, paradoxically, very few address 
the basic systematic questions (i.e. species description, revision, identification) at a very broad scale. As an illustration of that deficiency, it is worth pointing out that there is, for instance, no European equivalent of the Michener et al. (1994) key for the North American bees.

The development and availability of relevant taxonomic expertise is therefore a main constraint when conducting bee surveys in $\mathrm{Eu}-$ rope. Approaches are basically restricted (i) to the taxa for which expertise exist; (ii) by the time for acquisition of new expertise. For the genus Andrena F. ( $7.5 \%$ of the world diversity of bees), more than 50000 undetermined specimens are conserved in the museum of Linz (Austria) (Gusenleitner, unpubl. data). This unique example highlights the extent of the current deficiency in taxonomic expertise. These observations argue for the promotion of the development of the taxonomic expertise.

More than a simple tool used to measure diversity, taxonomy also acts to reveal diversity and species richness. For instance, considering ten recent studies (conducted by us and our collaborators) of taxa present in the WestPalaearctic, the taxonomic revisions have led to an average $14 \%$ increase in recognised species (Tab. III). Even more dramatically, for African taxa the contribution of taxonomy to the knowledge of diversity resulted in an increase of $\sim 40 \%$ of the known taxa (Tab. III).

Diversity can however be estimated using alternative taxonomic methods such as morphospecies (Oliver and Beattie, 1996; Basset et al., 2004) or parataxonomy (Basset et al., 2004; Janzen, 2004; Krell, 2004). The information acquired by such methods provides in the short term a snapshot estimate of the $\alpha$ - and $\beta$-diversity (i.e. how many taxa co-exist and how taxon turn-over in the study area functions in the short-term). However, major issues go together with the use of these methods. The error rate can increase dramatically according to the group considered (e.g., groups with a very high evolutionary rate), the training given to field workers, etc. These issues are particularly severe in bees, in which morphologically similar and cryptic species are notably common in every major group (e.g.,
Rasmont, 1984; Schmidt and Westrich, 1993; Patiny et al., 2005).

A consequence of these issues is that the equivalence between morphospecies of two distinct studies is almost impossible to assess, and thus the $\alpha$ - and $\beta$-diversity can never be combined to evaluate the regional $\gamma$-diversity. Therefore, these methods prevent nearly absolutely any follow-up of the studied fauna over the mid- or long-terms. Finally, the strict reliance on such alternative method also prevents detection of new taxa, whereas these are still numerous in bees even in well inventoried areas (Tab. III).

\section{SURVEYS, MONITORING AND NORTH WEST PALAEARCTIC BEES}

\subsection{Surveys}

Surveys and monitoring are two ways to measure species richness. To avoid confusion, we distinguish between surveys and monitoring, as they correspond to distinct practices. Surveys are usually short term projects (perhaps a few years) and aim to generate optimal data coverage for defined areas. Fieldwork and biological material acquired in the framework of the project itself play a central role. Information from survey programs provides the background for estimating species richness, turnover, etc. and comparing the faunas of distinct geographical regions. Despite the value of surveys in defining species richness and distributions in the defined areas in a given time period, surveys lack an essential dimension to depict changes in diversity: time (Magurran, 2005a, b, 2007).

\subsection{Extensive monitoring}

Extensive monitoring is central to understanding changes in species richness and diversity, as was pinpointed by authors like Cane et al. (2005). For monitoring to succeed it must be based on optimized and standardized methodologies, and recent work has been aimed at developing such methodologies for bees (Williams N.M. et al., 2001; Westphal et al., 2008). 
We define extensive monitoring as programs aiming at compiling data over a long time-span (e.g., decades) and from an array of different sources: literature, museum, field, etc. coupled with a continuous acquisition of new field data. One fundamental difference between surveys and monitoring is the attention paid to the temporal dimension and its impact on changes in species richness (Weber et al., 2004; Magurran, 2005a, b, 2007). Another difference is the heterogeneity of the data sources. In surveys, data are derived purely from the field and thus are internally consistent. In monitoring, as one is gathering data from multiple sources, the data are naturally heterogeneous in type, and thus require standardization prior to statistical treatment.

\subsection{Common issue}

A common issue arises in the framework of both surveys and monitoring. Because bees are often highly specialized (floral choices, nesting, phenology e.g.), their populations can undergo strong spatio-temporal variations, which constitute a major source of bias in survey and monitoring initiatives (Petanidou et al., 2008). In the framework of intensive surveys, the spatio-temporal variations of populations are problematic with reference to the sufficiency of the records. The combination of distinct and standardized sampling techniques can help in partly bypassing this impediment (Westphal et al., 2008; Williams N.M. et al., 2001). In the framework of monitoring, the sufficiency of the records is less of a concern. The long term over which the programs are developed should make it possible to overcome the bias that may result from the spatio-temporal variations in populations. However, as a corollary, the records gathered are naturally heterogeneous and need the application a posteriori of standardization and smoothing methods (see relevant references and an example in Patiny et al., 2009).

\subsection{North West Palaearctic bees}

The former EIS-CIE-EEW (i.e. European Invertebrate Survey: http://www. eis-international.org/index.php) promoted some decades ago the creation of national initiatives for monitoring of invertebrates, including bees (Heath and Leclercq, 1969). If EIS has become somewhat effete and at least no more visibly active on the front stage of conservation, several affiliated initiatives are still active. The following databasing programs are managing large amount of data concerning West-Palaearctic bees:

(i) BDFGM (a.k.a. Banque de Données Fauniques Gembloux-Mons): developed by the Gembloux (FuSaGx) and Mons (UMH) universities in Belgium (http://www. atlashymenoptera.net/);

(ii) BWARS database (a.k.a. Bees Wasps and Ants Recording Society): developed by the members of the Bees Wasps and Ants Recording Society (http://www.bwars.com/);

(iii) NEV database (a.k.a. Nederlandse Entomologische Vereniging): developed by the members of the Hymenoptera section of the Netherlands Entomological Society (http:// www.nev.nl/hymenoptera/).

It is worth noting that none of these initiatives is institutional and, despite the importance and relevance of the work done, they rely for their main part on small groups of volunteers. The data collected have largely contributed to feed some large public programs (e.g., BWARS data contributes to the listing of UK Biological Action Plan species). As other authors before, we emphasize that detecting changes in species richness requires a huge effort in time and manpower, which can no longer be entirely supported by academics or institutional workers (Weber et al., 2004). The role played by high skilled volunteers is thus central, while the professional work focuses on the methodology and the analysis of the survey or monitoring results.

The monitoring realized for bees in the framework of the above initiatives extends, contrary to surveys, over space and time. The constituted databases include historical as well as modern records for a defined area which is sampled as comprehensively as possible. The data gathered in such databases can then be used by other bodies (e.g., the recent EUfunded ALARM project) to document any 
declines in richness and distribution of bees (Biesmeijer et al., 2006; Stokstad, 2006).

The make-up of such extensive database goes hand-in-hand with a series of pitfalls to which final users have to pay attention and for which methodological solutions must be researched. Surveying large period of time as well as large territories implies that the data gathered are particularly heterogeneous and produced by a wide range of sampling methods (from occasional collecting to highly standardized sampling). The analysis of such data implies that an increased attention is paid to the development and application of standardization, smoothing methods, etc. along both, the spatial and temporal dimensions. The choice of the methods for analyzing monitoring is therefore restricted to methods compatible with these features of the datasets.

In the last twenty years, the analysis of such databased information has served as the basis of various studies aiming at the description of the factors driving the distribution of species (Patiny and Michez, 2007; Patiny et al., 2009), the diversity erosion (formerly called faunistic drift) (Rasmont and Mersch, 1988; Rasmont et al., 1993, 2005; Patiny, 1998) and the factors underlying that diversity erosion.

\section{CONCLUSIONS AND FUTURE LINES OF RESEARCH}

Faced by the challenge of the widely acknowledged erosion of the bee diversity, the conservation strategies developed for these organisms in the West-Palaearctic needs a rapid and strong improvement. A few regions have been the object of surveys and monitoring, which reveal that erosion can be strong in some parts of the West-Palaearctic. However, the general knowledge of the bee species richness distribution in the subregion suggests that none of the richest faunas have been really monitored so far, whereas their populations are likely at risk, as are those of the northern areas.

The main threats identified in the monitored regions are habitat fragmentation and loss, the impact of the use of pesticides, changes in agricultural practices and their consequences for natural cycles, notably the intensification of several cropping practices. We hypothesize that these threats also weigh on the faunas of the West-Palaearctic richest areas. In addition, the most southern part of the WestPalaearctic (North-Africa, Western Arabian Peninsula, e.g.) is also threatened by the increase of local drought as a result of global climate change.

Conservation of the West-Palaearctic bees requires the development and inauguration of an efficient monitoring program. Several initiatives are ongoing as the natural heirs of the former EIS. The structure and experience of the teams leading these programs could constitute a valuable starting seed for the development of a well-designed monitoring program at the subregional scale.

Regarding the importance of the ecological service delivered by bees, such a monitoring initiative at the scale of the subregion is highly desirable. The expected outcomes would likely be valuable insights for the development of consistent and relevant conservation strategies.

\section{ACKNOWLEDGEMENTS}

The authors wish to thank sincerely Dr. Mark J.F. Brown for having provoked the present review, as well as for his kind and very relevant editorial work. We also thank Dr N.J. Vereecken for kindly authorising the reproduction of one of its photographs (Fig. 4) and Dr C. Praz (currently Cornell University, USA) for his useful comments on the early manuscripts.

Le point sur le statut des abeilles sauvages dans la région ouest-paléarctique.

Apoidea / diversité écologique / taxonomie / Europe / protection

Zusammenfassung - Eine Erhebung und eine Übersicht über den Stand der Wildbienen in der westlichen paläarktischen Region. Weltweit beläuft sich der Wert der der Bestäubung von Nutzpflanzen auf hunderte von Milliarden \$US. Ein bedeutender Anteil davon entfällt auf die Tätigkeit von Bestäubern, insbesondere Bienen, deren zu beobachtende Abnahme daher eine globale Bedrohung dastellt. Darüber hinaus betrachten wir 
die relevanten Erfassungsstrategien in der westlichen paläarktischen Region. Der vorliegende Artikel will die bestehenden Möglichkeiten einer Risikoabschätzung für die Bienen der westlichen paläarktischen Region inventarisieren. Wir stellen verfügbare Informationsquellen vor, in denen die Diversität der Bienen in der westlichen parläarktischen Unterregion dokumentiert sind. Darüber hinaus betrachten wir die relevanten Erfassungsstrategien der Bienendiversität.

Die Kenntnisse über die europäische Bienenfauna (69 Gattungen und 2048 Arten, nach Polaszek 2005) ist nun robust genug, eine erste Analyse des Artenreichtums und Verteilung der Arten zu ermöglichen (Abb. 1). Als Daumenregel beherbergen die mediterranen Ökosysteme reichere Faunen. Verschiedene ökologische Merkmale können diese Polarität in der Verteilung des Artenreichtums erklären: (i) das günstigere Energie- und Wassergleichgewicht; (ii) die Rolle dieser Gebiete während der quaternären Vergletscherungen; (iii) die Zunahme des Artenreichtums durch die Spezialisierungen in Wüstenpopulationen; (iv) die Rolle von Trockengebieten in der frühen Diversifikation.

Der Wissenshintergrund ist für die östlichen und südlichen Teile der West-Paläearktis merklich schwächer und skizzenhafter. Nichtsdestoweniger wurde gezeigt, dass die Verteilung des Artenreichtums in der nördlichen und südlichen Sahara Afrikas von dem Energie- und Wassergleichgewicht bestimmt wird. Diese Schlussfolgerungen sind leicht mit denen Michener's (1979) in Einklang zu bringen. Wo Wasser keinen begrenzenden Faktor darstellt, folgt der Artenreichtum einem Breitengradienten.

In einigen europäischen Ländern stehen bis zu $65 \%$ der Bienenarten auf der roten Liste. Die ermittelten hauptsächlichen Gründe für die Bedrängnis der Arten sind: (i) Stückelung der Habitate und Änderungen der Landnutzung; (ii) Abnahme der Blütendiversität und Blütenanzahl (Abb. 3); (iii) Insektizide und die direkte und indirekte Toxizität anderer landwirtschaftlicher Ausbringungen (wie z.B. Auswirkungen von Stickstoffablagerungen); (iv) physikalische Hindernisse (z.B. Fernstrassen). Ähnliche Beeinträchtigungen betreffen mit hoher Wahrscheinlichkeit auch die südliche und östliche westpaläarktische Region.

Erhaltungsmaßnahmen stützen sich auf Populationserfassungen und Taxonomie. Während des zweiten Teils des zwanzigsten Jahrhunderts kam es zu einer starken Verarmung an europäischen Bienentaxonomen. Jedoch gibt es mehrere Initiativen, die sich mit der Erfassung der Bienen und der $\mathrm{Zu}-$ sammenstellung von Datensammlungen befassen und deren gesammelten Daten von anderen Körperschaften genutzt wurden (z. B. ALARM).

Angesichts der offensichtlichen Abnahme der Bienendiversität müssen die für diese Tiere entwickelten Erhaltungsstrategien verbessert werden. Das Wissen über die Verteilung des Reichtums an Bie- nenarten weist darauf hin, dass keine der artenreichsten Faunen bislang wirklich erfasst wurden, während sie gleichzeitig stark bedroht sind. Erhaltungsmaßnahmen setzen die Entwicklung effizienter Erfassungsprogramme voraus. Die Erfahrungen der derzeitigen Arbeitsgruppen stellen einen wertvollen Ausgangspunkt für eine solche Entwicklung auf unterregionaler Ebene dar.

\section{Diversität / Taxonomie / West-Paläarktik / Euro- pa / Apoidea}

\section{REFERENCES}

Amiet F. (1994) Rote Listen der gefährdeten Bienen der Schweiz, in: Duelli P. (Ed.), Rote Listen der gefährdeten Tierarten in der Schweiz, BUWAL, Bern. [online] http://www.bafu.admin. $\mathrm{ch} /$ publikationen/publikation/00913/index.html? lang=de (accessed on 9 February 2009).

Ascher J.S., Rozen Jr. J.G., Schuh T. (2008) Apoidea species guide. [online] http://www.discoverlife. org (accessed on 9 February 2009).

Ashmann T.L., Knight T.M., Steets J.A., Amarasekare P., Burd M. (2004) Pollen limitation of plant reproduction: ecological and evolutionary causes and consequences, Ecology 85, 2408-2421.

Banaszak J. (1991) A checklist of the bee-species (Apoidea) of Poland with remarks to their taxonomy and zoogeography, Acta Univ. Lodziensis 7, $15-66$.

Basset Y., Novotny V., Miller S.E., Weiblens G.D., Missa O., Stewart A.J.A. (2004) Conservation and biological monitoring of tropical forests: the role of parataxonomists, J. Appl. Ecol. 41, 163-174.

Berggren K.T., Ellegren H., Hewitt G.M., Seddon J.M. (2005) Understanding the phylogeographic patterns of European hedgehogs, Erinaceus concolor and E. europaeus using the MHC, Heredity 95, 84-90.

Bieri S. (2002) Bienen und Wespen des Fürstentums Liechtenstein, Naturkundliche Forschung im Fürstentum Liechtenstein 19, 1-160.

Biesmeijer J.-C., Roberts S.P.M., Reemer M., Ohlemüller R., Edwards M., Peeters T., Schaffers A.P., Potts S.G., Kleukers R., Thomas C.D., Settele J., Kunin W.E. (2006) Parallel declines in pollinators and insect-pollinated plants in Britain and the Netherlands, Science 313, 351-354.

Bogusch P., Straka J., Kment P. (2007) Annotated checklist of the Aculeata (Hymenoptera) of the Czech Republic and Slovakia. Komentovaný seznam žahadlových blanokrídlých (Hymenoptera: Aculeata) Ceské republiky a Slovenska, Acta Entomol. Mus. Natl. Pragae Suppl. 11, 1-300. 
Borges P.A.V. (2005) Hymenoptera, in: Borges P.A.V., Cunha R., Gabriel R., Martins A.F., Silva L., Vieira V. (Eds.), A list of the terrestrial fauna (Mollusca and Arthropoda) and flora (Bryophyta, Pteridophyta and Spermatophyta) from the Azores, Direcção Regional de Ambiente and Universidade dos Açores, Horta, Angra do Heroísmo and Ponta Delgada, pp. 21-68.

Broström A., Coe M., Harrisson S.P., Gallimore R., Kutzbach J.E., Foley J., Prentice I.C., Behling P. (1998) Land surface feedbacks and palaeomonsoons in northern Africa, Geophys. Res. Lett. 25, 3615-3618.

Buchmann S.L., Nabhan G.P. (1996) The forgotten pollinators, Island Press, Shearwater books, Washington DC.

Buchmann S., Ascher J.S. (2005) The plight of pollinating bees, Bee World 86, 71-74.

Cane J.H., Tepedino V.J. (2001) Causes and extent of declines among native North American invertebrate pollinators: detection, evidence, and consequences, Conserv. Ecol. 5, 1.

Cane J.H., Minckley R., Kervin L., Roulston T. (2005) Temporally persistent patterns of incidence and abundance in a pollinator guild at annual and decadal scales: the bees of Larrea tridentata, Biol. J. Linn. Soc. 85, 319-329.

Convention on Biological Diversity (2001) The international initiative for the conservation and sustainable use of pollinators: A proposal for a plan of action. SBSTTA 7th Meeting, Item 5.1, 9 p.

Ceballos G., Dusmet y Alonso J.M., Del junco y Reves J. (1956) Catalogo de los Himenopteros de España, Madrid.

Cody M.L. (1975) Towards a theory of continental species diversities: bird distributions over Mediterranean habitat gradients, in: Cody M.L., Diamond J.M. (Eds.), Ecology and Evolution of Communities, Harvard University Press, Cambridge, MA, pp. 214-257.

Costanza R., d'Arge R., deGroot R., Farber S., Grasso M., Hannon B., Limburg K., Naeem S., O’Neill R.V., Paruelo J., Raskin R.G., Sutton P., van den Belt M. (1997) The value of the World's ecosystem services and natural capital, Nature 387, 253259.

Crist T.O., Veech J.A., Gering J.C., Summerville K.S. (2003) Partitioning Species Diversity across Landscapes and Regions: A Hierarchical Analysis of $\alpha, \beta$, and $\gamma$ Diversity, Am. Nat. 162, 734-743.

Dafni A., Shmida A. (1996) The possible ecological implications of the invasion of Bombus terrestris (L.) (Apidae) at Mt Carmel, Israel, in: Matheson A., Buchmann S.L., O'Toole C., Westrich P., Williams I.H. (Eds.), The conservation of bees, Linnean Society of London, International Bee Research Association, London, pp. 183-200.
Danforth B.N., Brady S.G., Sipes S.D., Pearson A. (2004) Single-copy nuclear genes recover Cretaceous-age divergences in bees, Syst. Biol. 53, 309-326.

Davies G.B.P., Brothers D.J. (2006) Morphology of Scrapter (Hymenoptera: Anthophila: Colletidae), with description of three new species and taxonomic status of five Cockerell taxa, Afr. Invertebr. 47, 135-183.

Davies G.B.P., Eardley C.D., Brothers D.J. (2005) Eight new species of Scrapter (Hymenoptera: Apoida: Colletidae) with descriptions of $S$. albifumus and $S$. amplispinatus females and a major range extension of the genus, Afr. Invertebr. 46, 141-179.

De Lattin G. (1967) Grundriss der Zoogeographie, Gustav Fischer Verlag.

Diniz M.d.A. (1960) Notas sobre himenópteros de Portugal, Memórias e Estudos do Museu Zoológico da Universidade de Coimbra 266, 1-37.

Eardley C.D., Kuhlmann M. (2006) Southern and East African Melitta Kirby (Apoidea: Melittidae), Afr. Entomol. 14, 293-305.

Eickwort G.C., Ginsberg H.S. (1980) Foraging and mating behavior in Apoidea, Annu. Rev. Entomol. $25,421-446$.

Elfving R. (1968) Die Bienen Finlands, Helsinki, Finlande.

Engel M.S. (2000) A new interpretation of the oldest Fossil Bee (Hymenoptera: Apidae), Am. Mus. Nov. 3296, 1-11.

Engel M.S. (2001) A monograph of the Baltic Amber bees and evolution of the Apoidea (Hymenoptera), Bull. Am. Mus. Nat. His. 259, 1-192.

Fellendorf M., Mohra C., Roberts S., Wirtz P., van der Zanden G. (1999) The bees of Madeira (Hymenoptera, Apoidea), Bocagiana, Museu Municipal do Funchal (História Natural), Madeira 197, 1-17.

Fitton M.G., de V. Graham M.W.R., Boucek Z.R.J., Fergusson N.D.M., Huddleston T., Quinlan J., Richards O.W. (1978) Hymenoptera, in: Kloet G.S., Hincks W.D. (Eds.), A checklist of British insects. Handbooks for the identification of British insects, 2nd ed., Royal Entomological Society of London, London, p. 159.

Fitzpatrick U., Murray T.E., Byrne A., Paxton R.J., Brown M.J.F. (2006) Regional red list of Irish bees. General report. National Parks and Wildlife Service, Dublin, and Environment and Heritage Service, Belfast. [online] http://www.npws.ie/ (accessed on 9 February 2009).

Friese H. (1901) Die Bienen Europa's (Apidae europaeae) nach ihren Gattungen, Arten und Varietäten auf vergleichend morphologischbiologischer Grundlage. Teil VI Solitäre Apiden: 
subfam. Panurginae, Melittinae, Xylocopinae. Selbstverlag - C. Lampe.

Gallai N., Salles J.-M., Settele J., Vaissière B. (2009) Economic valuation of the vunerability of world agriculture confronted with pollinator decline, Ecol. Econ. 68, 810-821.

Gärdenfors U., Ed. (2005) Rödlistade arter i Sverige 2005 - the 2005 red list of Swedish species. ArtDatabanken, The Swedish Species Information Centre, Uppsala. [online] http://www.nhbs.com/ rodlistade_arter_i_sverige_2005_the_2005_ tefno_141838.html (accessed on 9 February 2009).

Gogala A. (1999) Bee fauna of Slovenia: Checklist of species (Hymenoptera, Apoidea), Scopolia 42, 179.

Haddad N., de Miranda J.R., Bataena A. (2008) Discovery of Apis florea in Aqaba, Jordan, J. Apic. Res. and Bee World 47, 172-173.

Heath J., Leclercq J. (1969) The European Invertebrate Survey, Neth. J. Zool. 20, 148-149.

Hendrickx F., Maelfait J.-P., Van Wingerden W., Schweiger O., Speelmans M., Aviron S., Augenstein I., Billeter R., Bailey D., Bukacek R., Burel F., Diekötter T., Dirksen J., Herzog F., Liira J., Roubalova M., Vandomme V., Bugter R. (2007) How landscape structure, land-use intensity and habitat diversity affect components of total arthropod diversity in agricultural landscapes, J. Appl. Ecol. 44, 340-351.

Hewitt G.M. (1999) Post-glacial re-colonization of European biota, Biol. J. Linn. Soc. 68, 87-112.

Hohmann H., La Roche F., Ortega G., Barquin J. (1993) Bienen, Wespen und Ameisen der Kanarischen Inseln (Insecta: Hymenoptera: Aculeata), Bremen.

Iserbyt S., Durieux E.-A., Rasmont P. (2008) The remarkable diversity of bumblebees (Hymenoptera: Apidae: Bombus) in the Eyne Valley (France, Pyrénées-Orientales), Ann. Soc. Entomol. Fr. (n.s.) 44, 211-241.

Janzen D.H. (2004) Setting up tropical biodiversity for conservation through non-damaging use: participation by parataxonomists, J. Appl. Ecol. 41, 181187.

Joger U., Fritz U., Guicking D., Kalyabina-Hauf S., Nagy Z.T., Wink M. (2007) Phylogeography of western Palaearctic reptiles - Spatial and temporal speciation patterns, Zool. Anz. 246, 293-313.

Kevan P.G., Phillips T.P. (2001) The economic impacts of pollinator declines: an approach to assessing the consequences, Conserv. Ecol. 5, 8.

Klein A.-M., Vaissière B., Cane J.H., Steffan-Dewenter I., Cunningham S.A., Kremer C., Tscharntcke T. (2007) Importance of pollinators in changing landscapes for world crops, Proc. R. Soc. Lond. B 274, 303-313.
Krell F.T. (2004) Parataxonomy vs. taxonomy in biodiversity studies - pitfalls and applicability of 'morphospecies' sorting, Biodivers. Conserv. 13, 795812.

Kuhlmann M. (2005) Faunistik und Zoogeographie der Bienengattung Colletes Latreille 1802 (Hymenoptera: Apidae: Colletinae) in Mittelasien, Linz. Biol. Beitr. 37, 1353-1396.

Leclercq J., Gaspar C., Marchal J.-L., Verstraeten C., Wonville C., (1980) Analyse des 1600 premières cartes de 1'Atlas provisoire des Insectes de Belgique, et première liste rouge d'Insectes menacés dans la faune belge, Notes Fauniques Gembloux 4, 1-104

Levis S., Bonan G.B., Bonfils C. (2004) Soil feedback drives the mid-Holocene North African monsoon northward in fully coupled CCSM2 simulations with a dynamic vegetation model, Clim. Dyn. 23, 791-802.

Linsley E.G. (1958) The ecology of solitary bees, Hilgardia 27, 543-599.

Lopezaraiza-Mikel M.E., Hayes R.B., Whalley M.R., Memmott J. (2007) The impact of an alien plant on a native plant-pollinator network: an experimental approach, Ecol. Lett. 10, 539-550.

Losey J., Vaughan M. (2006) The Economic Value of Ecological Services Provided by Insects, BioScience 56, 311-323.

Magurran A.E. (2005a) Species abundance distributions: pattern or process? Funct. Ecol. 19, 177181.

Magurran A.E. (2005b) Biological diversity, Curr. Biol. 15, 116-118.

Magurran A.E. (2007) Species abundance distributions over time, Ecol. Lett. 10, 347-354.

Memmott J., Craze P.G., Waser N.M., Price M.V. (2007) Global warming and the disruption of plant - pollinator interactions, Ecol. Lett. 10, 710-717.

Michener C.D. (1979) Biogeography of the bees, Ann. Mo. Bot. Gard. 66, 277-342.

Michener C.D. (2007) The Bees of the World, 2nd ed., Johns Hopkins University Press, Baltimore.

Michener C.D., McGinley R.J., Danforth B.N. (1994) The bee genera of north and central America (Hymenoptera: Apoidea), Smithsonian Institution.

Michez D., Eardley C.D. (2007) Monographic revision of the bee genus Melitta Kirby 1802 (Hymenoptera: Apoidea: Melittidae), Ann. Soc. Entomol. Fr. (n. s.) 43, 379-440.

Michez D., Patiny S. (2006) Review of the bee genus Eremaphanta Popov 1940 (Hymenoptera: Melittidae), with the description of a new species, Zootaxa 1148, 47-68.

Michez D., Terzo M., Rasmont P. (2004) Révision des espèces ouest-paléarctiques du genre 
Dasypoda Latreille 1802 (Hymenoptera, Apoidea, Melittidae), Linz. Biol. Beitr. 36, 847-900.

Michez D., Eardley C.D., Kuhlmann M., Patiny S. (2007) Revision of the bee genus Capicola (Hymenoptera: Apoidea: Melittidae) distributed in the Southwest of Africa, Eur. J. Entomol. 104, 311-340.

Minckley R.L., Cane J.H., Kervin L. (2000) Origins and ecological consequences of pollen specialization among desert bees, Proc. R. Soc. Lond. B 267, 265-271.

Monsevicius V. (1995a) A check-list of wild bee species (Hymenoptera, Apoidea) of Lithuania with data to their distribution and bionomics, in "New and rare for Lithuania insect species. Records and descriptions of 1994-1995". Institute of Ecology Lithuanian Entomological Society, Vilnius, pp. 7-144.

Monsevicius V. (1995b) Fauna of Wild Bees in Lithuania and trends of its changes, in: Banaszak J. (Ed.), Changes in Fauna of Wild Bees in Europe, Pedagogical University, Bydgoszcz, pp. 27-32.

Müller A., Kuhlmann M. (2008) Pollen hosts of western Palaearctic bees of the genus Colletes (Hymenoptera: Colletidae): the Asteraceae paradox, Biol. J. Linn. Soc. 95, 719-733.

Müller A., Diener S., Schnyder S., Stutz K., Sedivy C., Dorn S. (2006) Quantitative pollen requirements of solitary bees: Implications for bee conservation and the evolution of bee-flower relationships, Biol. Conserv. 130, 604-615.

Murray T.E., Kuhlmann M., Potts S.G. (2009) Conservation ecology of bees: populations, species and communities, Apidologie 40, 211236.

Nilsson L.A. (2003) Prerevisional checklist and synonymy of the bees of Sweden (Hymenoptera: Apoidea). Preliminary report, Swedish Wild Bee Project, ArtDatabanken.

Oliver I., Beattie A.J. (1996) Invertebrate morphospecies as surrogates for species: a case study, Conserv. Biol. 10, 99-109.

Oldroyd B.P. (2007) What's killing American Honey Bees, PLoS Biol. 5, 4.

Osytschnjuk A.Z. (1977) Fauna Ukrainy, Tom 12, Apoidea, Bienen, Teil 5, Andrenidae. Akademia Nauk Ukrainskoj RSR, Kiev "Naukova Dumka".

Pagliano G. (1994) Hymenoptera Apoidea, in: Minelli A., Ruffo S., La Posta S., Checklist Delle Specie Della Fauna Italiana, Fascicolo 106, Calderini, Bologna, pp. 25. [online version] http://www. faunaitalia.it/checklist/ (accessed on 9 February 2009).

Patiny S. (1998) Contribution à la connaissance de la régression des populations du sous-genre Taeniandrena Hedicke, 1933 (Hym., Andrenidae, Andrena) et de leurs habitudes pollinisatrices, Notes Fauniques Gembloux 35, 20-33.
Patiny S. (1999a) Systématique générique et subgénérique des Melitturga LatreilleMeliturgula Friese-Flavomeliturgula (Warncke) (Hymenoptera: Andrenidae, Panurginae), Bull. Soc. Entomol. Fr. 104, 241-256.

Patiny S. (1999b) Révision des Panurginae ouestpaléarctiques n'appartenant pas à la tribu des Melitturgini Michener, 1944 (Hymenoptera, Andrenidae) - Partie 1: Panurgus Panzer et Camptopoeum Spinola, Entomofauna 20, 309328.

Patiny S. (2001) Monographie des Panurginae de l'ancien monde (Hymenoptera: Apoidea, Andrenidae), Thèse de doctorat, Faculté universitaire des Sciences agronomiques de Gembloux.

Patiny S. (2004) Analysis of the Panurginae distribution in West-Africa and report of new data for Meliturgula scriptifrons (Walker 1871) in Mali (Hymenoptera, Apoidea, Andrenidae), Linz. Biol. Beitr. 36, 901-906.

Patiny S., Gaspar C. (2000) Biogéographie des Melitturga Latreille, 1809, Meliturgula Friese, 1903 et des genres proches (Hymenoptera: Andrenidae, Panurginae), Notes Fauniques Gembloux 39, 3-44.

Patiny S., Michez D. (2006) Phylogenetic analysis of the Systropha Illiger, 1806 (Hymenoptera: Halictidae) and description of a new subgenus, Ann. Soc. Entomol. Fr. (n.s.) 42, 27-44.

Patiny S., Michez D. (2007) Biogeography of bees (Hymenoptera, Apoidea) in Sahara and the Arabian deserts, Insect Syst. Evol. 38, 19-34.

Patiny S., Ortiz-Sanchez F.J., Michez D. (2005) A review of Panurgus (Pachycephalopanurgus), with the description of a new species from Spain, Zootaxa 1037, 37-48.

Patiny S., Michez D., Danforth B.N. (2008) Phylogenetic relationships and host-plant evolution within the basal clade of Halictidae (Hymenoptera, Apoidea), Cladistics 24, 255-269.

Patiny S., Michez D., Kuhlmann M., Pauly A., Barbier Y. (2009) Factors limiting the species richness of bees in Saharan Africa, Bull. Entomol. Res., doi: 10.1017/S0007485308006433.

Pauly A. (1999) Catalogues des hyménoptères aculéates de Belgique, Bull. Soc. R. Belg. Entomol. $135,98-125$

Peeters T., Raemakers I., Smit J. (1999) Voorlopige atlas van de Nederlandse bijen (Apidae), Leiden.

Pekkarinen A. (1997) Oligolectic bee species in Northern Europe (Hymenoptera, Apoidea), Entomol. Fenn. 8, 205-214.

Pesenko Y.A., Pauly A. (2005) Monograph of the bees of the subfamily Nomioidinae (Hymenoptera: Apoidea) of Africa (excluding Madagascar), Ann. Soc. Entomol. Fr. (n.s.) 41, 129-236. 
Petanidou T., Kallimanis A.S., Tzanopoulos J., Sgardelis S.P., Pantis J.D. (2008) Long-term observation of a pollination network: fluctuation in species and interactions, relative invariance of network structure and implications for estimates of specialization, Ecol. Lett. 11, 564-575.

Petersen B. (1956) Hymenoptera. In The Zoology of Iceland, Copenhagen \& Reykjavik, pp. 1-176.

Pimentel D., Wilson C., McCullum C., Huang R., Dwen P., Flack J., Tran Q., Saltman T., Cliff B. (1997) Economic and environmental benefits of biodiversity, Bioscience 47, 747-757.

Poinar G.O.J., Danforth B.N. (2006) A fossil bee from Early Cretaceous Burmese amber, Science 314, 614.

Popov V.V. (1967) Bees (Hymenoptera: Apoidea) of Central Asia and their distribution on flowering plants, rudy Zoologiceskogo Instituta, Akademiya Nauk SSSR, Leningrad 38, 11-329.

Polaszek A. (2005) Fauna Europea: Apidae, in: Noyes J. (Ed.), Fauna Europaea: Hymenoptera Apocrita, Version 1.2. [online] http://www.faunaeur.org (accessed on 9 February 2009).

Proctor M., Yeo P. (1973) The Pollination of Flowers, Collins.

Prys-Jones O., Olafsson E., Kristjánsson K. (1981) The Icelandic bumble bee fauna (Bombus Latr., Apidae) and its distributional Ecology, J. Apic. Res. 20, 189-197.

Rasmont P. (1984) Les Bourdons du genre Bombus Latreille sensu stricto en Europe Occidentale et Centrale (Hymenoptera, Apidae), Spixiana 7, 135-160.

Rasmont P. (2003) Jean-Henry Fabre pourrait-il observer aujourd'hui tous ces insectes ? in: Fabre J.-H. (Ed.), un autre regard sur l'insecte, Actes Colloq. Int. sur 1'Entomologie, 18-19 octobre 2002, Saint-Léons en Lévézou (France, Aveyron), Conseil général de l'Aveyron, Rodez, pp. 209220.

Rasmont P. (2008) La régression massive des espèces d'abeilles sauvages et de bourdons d'Europe : un effet de la perturbation mondiale du cycle de l'azote, in: Actes Colloq. Insectes et Biodiversité, 6 octobre 2006, Saint-Léons en Lévézou (France, Aveyron), Conseil général de l'Aveyron, Rodez, pp. 43-60.

Rasmont P., Mersch P. (1988) Première estimation de la dérive faunique chez les bourdons de la Belgique (Hymenoptera: Apidae), Ann. Soc. R. Zool. Belg. 118, 141-147.

Rasmont P., Leclercq J., Jacob-Remacle A., Pauly A., Gaspar C. (1993) The faunistic drift of Apoidea in Belgium, in: Bruneau E. (Ed.), Bees for pollination, Commission of the European Communities, pp. $65-87$.
Rasmont P., Ebmer A., Banaszak J., Van Der Zanden G. (1995) Hymenoptera Apoidea Gallica. Liste taxonomique des abeilles de France, de Belgique, de Suisse et du Grand-Duché de Luxembourg, Bull. Soc. Entomol. Fr. 100 (hors série), 1-98.

Rasmont P., Pauly A., Terzo M., Patiny S., Michez D., Iserbyt S., Barbier Y., Haubruge E. (2005) The survey of wild bees (Hymenoptera, Apoidea) in Belgium and France, Rapport d'activité, UMH FUSAGx - FAO, 18 p. [online] http://www.fao. org/ag/AGP/AGPS/C-CAB/Castudies/pdf/1-010. pdf (accessed on 9 February 2009).

Rassi P., Alanen A., Kanerva T., Mannerkoski I. (Eds.) (2001) The 2000 Red List of Finnish species, Ministry of the Environment and Finnish Environment Institute, Helsinki.

Reinig W.F. (1937) Holarktis. Ein Beitrag zur diluvialen und alluvialen Geschichte der zirkumpolaren Faunen und Florengebiete, Gustav Fischer, Jena.

Renner S.S. (1998) Effects of habitat fragmentation on plant pollinator interactions in the tropics, in: Newbery D.M., Prins H.H.T., Brown N.D. (Eds.), Dynamics of Tropical Communities, Blackwell Scientific Publishers, Oxford, pp. 339-360.

Richards O.W. (1979) The Hymenoptera Aculeata of the Channel Islands, Report and Trans. Soc. Guernsey 20, 389-424.

Roig-Alsina A., Michener C.D. (1993) Studies of the phylogeny and classification of long-tongued bees (Hymenoptera: Apoidea), Univ. Kans. Sc. Bull. $55,123-173$.

Schmidt K., Westrich P. (1993) Colletes hederae n. sp., eine bisher unerkannte, auf Efeu (Hedera) spezialisierte Bienenart (Hymenoptera: Apoidea), Entomol. Z. 103, 89-93.

Schwarz M., Gusenleitner F. (1997) Neue und ausgewählte Bienenarten für Österreichs: Vorstudie $\mathrm{zu}$ einer Gesamtbearbeitung der Bienen Österreichs (Hymenoptera: Apidae), Entomofauna (Ansfelden) 18, 301-372.

Schwarz M., Gusenleitner F. (1999) Weitere Angaben zur Bienenfauna Österreichs. Vorstudie $\mathrm{zu}$ einer Gesamtbearbeitung der Bienen Österreichs II (Hymenoptera, Apidae), Entomofauna (Ansfelden) 20, 185-256.

Schwarz M., Gusenleitner F., Westrich P., Dathe H.H. (1996) Katalog der Bienen Österreichs, Deutschlands und der Schweiz (Hymenoptera, Apidae), Entomofauna Suppl. 8, 1-398.

Shepherd M., Buchmann S.L., Vaughan M., Black S.H. (2003) Pollinator conservation handbook, The Xerces Society, Portland, Oregon.

Spuris Z. (1998) Red data book of Latvia - rare and threatened species of plants and animals, Vol. 4, Invertebrates, Institute of biology University of Latvia, Rîga, 388 p. 
Stelfox A.W. (1927) A list of the Hymenoptera Aculeata (sensu lato) of Ireland, Proc. R. Irish Acad. 37, 201-355.

Stokstad E. (2006) Pollinator Diversity Declining in Europe, Science 313, 286.

Stout J.C., Morales C.L. (2009) Ecological impacts of invasive alien species on bees, Apidologie 40, 388-409.

Straka J., Bogusch P., Pridal A. (2008) Apoidea: Apiformes (vèely), in: Annotated checklist of the Aculeata (Hymenoptera) of the Czech Republic and Slovakia, Acta Entomol. Mus. Natl. Pragae Suppl. 11 (2007) 308 p.

Terzo M., Rasmont P. (2004) Biogéographie et systématique des abeilles rubicoles du genre Ceratina Latreille au Turkestan (Hymenoptera, Apoidea, Xylocopinae), Ann. Soc. Entomol. Fr. (n. s.) 40, 109-130.

Thorp R.W. (1979) Structural behavioral, and physiological adaptations of bees (Apoidea) for collecting pollen, Ann. Mo. Bot. Gard. 66, 788-812.

Thorp R.W. (2000) The collection of pollen by bees, Plant Syst. Evol. 222, 211-223.

Tylianakis J.M., Klein A.M., Tscharntke T. (2005) Spatiotemporal variation in the diversity of Hymenoptera across a tropical habitat gradient, Ecology, 86, 3296-3302.

Tylianakis J.M., Didham R.K., Bascompte J., Wardle D.A. (2008) Global change and species interactions in terrestrial ecosystems, Ecol. Lett. 11, 1351-1363.

Ungricht S., Müller A., Dorn S. (2008) A taxonomic catalogue of the Palaearctic bees of the tribe Osmiini (Hymenoptera: Apoidea: Megachilidae), Zootaxa 1865, 1-253.

Warncke K. (1973) Die westpaläarktische Arten der Bienen Familie Melittidae (Hymenoptera), Pol. Pismo Entomol. 43, 97-126.

Warncke K. (1979) Beitrag zur Bienenfauna des Iran 11. Die Gattung Pararhophites Fr., Bull. Mus. Civ. Stor. Nat. Venezia 30, 197-198.

Warncke K. (1986) Die Wildbienen Mitteleuropas ihre gültigen Namen und ihre Verbreitung (Insecta, Hymenoptera), Entomofauna 3 Suppl., 1-128.

Warncke K. (1987) Ergänzende untersuchungen an bienen der gattungen Panurgus und Melitturga/Andrenidae, Apidae, vor allem aus dem turkischen raum, Bull. Mus. Civ. Stor. Nat. Venezia 34, 75-107.
Weber D., Hintermann U., Zangger A. (2004) Scale and trends in species richness: considerations for monitoring biological diversity for political purposes, Glob. Ecol. Biogeogr. 13, 97-104.

Westphal C., Bommarco R., Carré G., Lamborn E., Morison N., Petanidou T., Potts S.G., Roberts S.P.M., Szentgyorgyi H., Tscheulin T., Vaissière B.E., Woyciechowski M., Biesmeijer J., Kunin W.E., Settele J., Steffan-Dewenter I. (2008) Measuring bee diversity in different European habitats and biogeographical regions, Ecol. Monogr. 78, 653-671.

Westrich P., Schwenninger H.R., Dathe H.H., Riemann H., Saure C., Voith J., Weber K. (1998) Rote Liste der Bienen (Hymenoptera: Apidae) Deutschlands, in: Boye P. (Ed.), Rote Liste gefährdeter Tiere Deutschlands, Federal Agency for Nature Conservation in Germany, Schriftenreihe für Landschaftspflege und Naturschutz, Heft 55.

Whitehead V.B., Steiner K.E. (2001) Oil-collecting bees of the winter rainfall area of South Africa (Melittidae, Rediviva), Ann. S. Afr. Mus. 108, 143-277.

Whitehead V.B., Steiner K.E., Eardley C.D. (2008) Oil collecting bees mostly of the summer rainfall area of southern Africa (Melittidae, Rediviva), J. Kans. Entomol. Soc. 81, 122-141.

Whittaker R.J., Willis K.J., Field R. (2001) Scale and species richness: towards a general, hierarchical theory of species diversity, J. Biogeogr. 28, 453 470.

Williams N.M., Minckley R.L., Silveira F.A. (2001). Variation in native bee faunas and its implications for detecting community changes, Conserv. Ecol. 5,7 .

Williams P.H. (1985) On the distribution of bumble bees (Hymenoptera, Apidae) with particular regard to patterns within the British Isles. PhD thesis, Department of Applied Biology, University of Cambridge, Cambridge, UK.

Williams P.H., Araújo M.B., Rasmont P. (2007) Can vulnerability among British bumblebee (Bombus) species be explained by niche position and breadth? Biol. Conserv. 138, 493-505.

Zanden (v.d.) G. (1958) Hymenotera aculeata van Andorra en de Franse Pyreneen, Entomol. Ber. 18, 89-91. 